\title{
Using "bryophytes and their associated testate amoeba" microsystems as indicators of atmospheric pollution
}

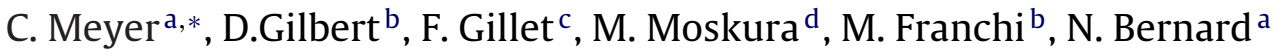 \\ a Department of Chrono-Environment, UMR 6249 CNRS, University of Franche-Comte, Place Leclerc, F-25030 Besançon, France \\ b Department of Chrono-Environment, UMR 6249 CNRS, University of Franche-Comte, 4 Place Tharradin, B.P. 71427 , F-25211 Montbéliard Cedex, France

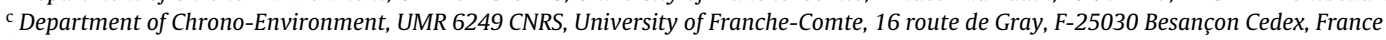 \\ d Groupe d'Analyses Elémentaires, Laboratoire Pierre Süe (CNRS/CEA), CEA Saclay, F-91191 Gif-sur-Yvette, France
}

\section{A R T I C L E I N F O}

\section{Article history:}

Received 22 December 2010

Received in revised form 16 May 2011

Accepted 23 May 2011

\section{Keywords:}

Bioindication

"Bryophyte-testate amoebae"

microsystems

$\mathrm{NO}_{2}$

Particulate deposition

\begin{abstract}
A B S T R A C T
Testate amoebae (TA) associated with terrestrial mosses are increasingly used in ecological and ecotoxicological studies. The TA community is sensitive to changes in its environment (climate change, metal or gas pollution). In this study, a "bryophyte-TA" microsystem was investigated as an indicator of dry particulate deposition and $\mathrm{NO}_{2}$ atmospheric concentration over an 8-month period in rural, urban and industrial sites in north-eastern France.

The urban site was characterised by significant contamination with $\mathrm{NO}_{2}$, and the industrial site by significant contamination with $\mathrm{Fe}, \mathrm{Pb}, \mathrm{Cr}$ and $\mathrm{Al}$. Different ecological descriptors of the TA community can be used as indicators of atmospheric pollution. Simple descriptors (total biomass or total abundance) are useful to indicate atmospheric particulate and gaseous pollution, while a complex descriptor (species richness) is useful to differentiate the source of pollution (urban or industrial) in winter and summer. Moreover, Redundancy Analysis showed that some species are negatively correlated with $\mathrm{NO}_{2}$ and particulate pollution. Principal Responses Curves revealed contrasting dynamics of the TA species biomass according to the type of pollution (urban or industrial).

Our results bring further support to the use of bryophytes and associated TA as a biomonitoring tool for atmospheric pollution. Further studies are required to develop this tool and standardise it for potential general use.
\end{abstract}

(c) 2011 Elsevier Ltd. All rights reserved.

\section{Introduction}

The impact of atmospheric pollution on organisms depends on the type and concentration of pollutants, the exposure period and the characteristics of the organism itself. Each year, many chemical compounds (organic or inorganic) are continuously released into the atmosphere from natural and anthropogenic sources (Thorpe and Harrison, 2008; Blake et al., 2009; Byrd et al., 2010). The potential risk for human health from airborne contaminants is determined by physico-chemical measurements. For instance, the European directive 2008/50/CE fixes the upper limit value for atmospheric concentrations of $\mathrm{NO}_{2}$ for health protection at $40 \mu \mathrm{g} \mathrm{m}^{-3}$ as an annual average and the upper limit value for protection of vegetation at $30 \mu \mathrm{g} \mathrm{m}^{-3}$, as an annual average. The World Health Organization (WHO) recommendations have been defined for $\mathrm{PM}_{10}$ (Particulate Matter with a diameter $\leq 10 \mu \mathrm{m}$ ) and fix the upper limit

\footnotetext{
* Corresponding author. Tel.: +33 3816657 10; fax: +33 381665797

E-mail address: caroline.meyer@univ-fcomte.fr (C. Meyer).
}

value for health protection at $50 \mu \mathrm{g} \mathrm{m}^{-3}$ as a daily average (decree no. $1999 / 30 / C E)$.

Understanding the impact of atmospheric pollutants on ecological systems such as microbial communities is challenging. Particulate pollution is complex because particle composition is heterogeneous (Alves et al., 2001; Gaudry et al., 2008; Slezakova et al., 2008; Han et al., 2009) and varies with primary sources and with the atmospheric environment (Alves et al., 2001). Moreover in situ particulate pollution is associated with other pollution, such as gaseous pollution. The measurement of these atmospheric pollutants using physico-chemical techniques alone does not suffice to determine the impact on organisms and the integration of these contaminants on the functioning of ecological systems. Several components of atmospheric pollutants can have an impact on organisms, and the effect of a mixture of pollutants is not equal to the sum of the effects of each of them (Martin-Gonzáles et al., 2006; Khan et al., 2007; Gallego et al., 2007; Nwuche and Ugoji, 2008). The biomonitoring approach, which is based on the sensitivity of organisms, is one solution to estimate the effect of complex air pollution on biological communities (Markert, 2007). Bioindicators, which are defined as an organism or a community that contains 
information on the quality of the environment (Markert, 2007), can integrate pollution over a long period of time. Among microbial organisms, testate amoebae have been shown to be useful for bioindication of anthropogenic pollution in peatland (Gilbert et al., 1999), lakes (Roe et al., 2010) and soils (Asada and Warner, 2009).

Testate amoebae (TA) are unicellular protists characterised by a decay-resistant test (Meisterfeld, 2000a,b). They live in a variety of habitats (aquatic environment, soil, and mosses) where they are directly exposed to pollutants. They are abundant and diverse in mosses (Smith et al., 2008). For example, Vincke et al. (2004) identified 83 taxa in the mosses on Île de la Possession, and Golemansky and Todorov (2000) identified 91 taxa in moss, soil and aquatic samples from Thailand. The unique shape of the rigid test, which remains identifiable even after the death of the organism, allows for species-level identification. TA have been used as a tool for the evaluation of past environmental changes (Mitchell et al., 2008).

Nevertheless, only few studies have been published on the use of TA community as potential bioindicators of pollutants. By the use of different ecological indices (biomass, species-specific response, abundance, and diversity indexes), these studies showed the potential bioindicator properties of the TA community for aquatic (Kauppila et al., 2006; Zhou et al., 2006) and atmospheric pollution (Nguyen-Viet et al., 2004, 2007a, 2008). The authors (Nguyen-Viet et al., 2004, 2007a) showed that species richness and TA abundance negatively correlated with atmospheric concentrations of $\mathrm{NO}_{2}$ in terrestrial bryophytes (Tortula muralis) in France and with atmospheric lead $(\mathrm{Pb})$ accumulated in Barbula indica in Vietnam. They showed a species-specific response to each pollutant: Paraquadrula irregularis was affected by $\mathrm{NO}_{2}$, whereas Euglypha ciliate form glabra and E. ciliata were affected by $\mathrm{Pb}$. Two studies have shown an impact of particulate pollution on the biomasses of microbial communities living in Pseudoscleropodium purum. In situ, Meyer et al. (2010a) showed that urban and industrial pollution had a negative impact on total TA biomass. Under controlled conditions, these authors showed a negative impact of a common level of urban particulate on the total biomass of an active TA community (Meyer et al., 2010b).

In this context, the aim of this study was to estimate the impact of dry deposition of atmospheric particles and atmospheric $\mathrm{NO}_{2}$ concentration on the TA community living in P. purum and to develop an indicator of atmospheric pollution. The TA community data obtained in our previous in situ study (Meyer et al., 2010a) has been reworked and expanded to better determine its role as a potential indicator. The effect of different atmospheric pollutions that were characterised by $\mathrm{NO}_{2}$ atmospheric concentrations and the concentrations of metal trace elements (MTEs) accumulated in bryophytes were estimated using different ecological indexes for the TA community (biomass, abundance, diversity, and species richness).

The main research questions of this study are:

(1) Is the TA community in P. purum affected by atmospheric pollution? If so, can we assume that the various types of pollution (rural, urban and industrial) have the same impact?

(2) Is there a response of the ecological index (e.g., structure of the community and diversity) for the TA community to the atmospheric pollution that could be used as a biological indicator of atmospheric pollution?

\section{Methods}

The study sites, the moss sampling and analysis and $\mathrm{NO}_{2}$ sampling and analysis were described in detail in Meyer et al. (2010a) and Fabure et al. (2010).

\subsection{Study sites}

Three sites were selected in north-eastern France according to their pollution sources. The rural site $(R)$ is located in Montagney (geographical location: N 47 $17^{\prime} 11^{\prime \prime}$; E $5^{\circ} 39^{\prime} 40^{\prime \prime}$; at an altitude of $192 \mathrm{~m}$ a.s.l.). The urban site (U) is located in Saclay (geographical

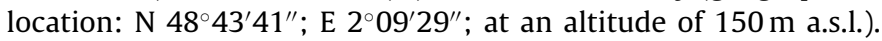
The industrial site (I) is located in Dunkirk (geographical location: $\mathrm{N} 51^{\circ} 2^{\prime} 16^{\prime \prime}$; E $2^{\circ} 22^{\prime} 35^{\prime \prime}$; at an altitude of $6 \mathrm{~m}$ a.s.l.) on the North Channel coast.

Meteorological data were collected at each site. Data from Meteo-France stations (temperature and humidity) located at the urban and industrial sites were used. For the rural site, these data were obtained from our own weather station (Data logger: DeltaT DL2e; PC software: LS2e; equipments: relative humidity and air temperature sensors).

\subsection{Moss sampling and transplanting}

In July 2005, samples of P.purum were taken from the Fontainebleau forest, an unpolluted site (geographical location: $\mathrm{N}$ $48^{\circ} 24^{\prime} 36^{\prime \prime}$, E $\left.2^{\circ} 37^{\prime} 50^{\prime \prime}\right)$. P. purum were placed in small containers $(15 \mathrm{~cm} \times 15 \mathrm{~cm}, 4 \mathrm{~cm}$ deep), without being washed beforehand, and were then acclimatised for three months at the rural site. Humidity was maintained in the moss containers using a system of capillarity wicks that absorbed Volvic mineral water (Aboal et al., 2008).

These containers were exposed at each site from October 2005 to June 2006 in three roofed shelters. Each shelter contained five small containers of $P$. purum. In each shelter, a small container was taken out every two months: October (samples T0), December, February, April and June. Each time, all the green parts of the stems were removed and mixed together. Then, random samplings of these moss stems were performed. Fifteen stems were put into $20 \mathrm{~mL}$ of glutaraldehyde ( $2 \%$ final concentration) for microbial community analysis. Approximately 50 stems were used for heavy metal analysis.

\subsection{Metal trace element analysis}

Metal trace elements (MTEs) in bryophytes were analysed by instrumental neutron activation (INAA) and by inductively coupled plasma mass spectrometry (ICP-MS). Concentrations of $\mathrm{Al}, \mathrm{Cr}, \mathrm{Fe}$, $\mathrm{Zn}$ and $\mathrm{Br}$ were determined by INAA, while concentrations of $\mathrm{Cu}$ and $\mathrm{Pb}$ were determined by ICP-MS.

\section{4. $\mathrm{NO}_{2}$ sampling and analysis}

Passive samplers were used (Palmes et al., 1976; ADEME, 2002). The passive samplers were removed every two weeks, and absorbed $\mathrm{NO}_{2}$ was measured by spectrophotometry. Mean concentration of $\mathrm{NO}_{2}\left(\mu \mathrm{g} \mathrm{m}^{-3}\right)$ in sampled air was calculated.

\subsection{Testate amoeba community extraction and analysis}

\subsubsection{Extraction}

The TA community was extracted from the mosses using the method described by Nguyen-Viet et al. (2007b) and Meyer et al. (2010a,b): each sample was first shaken in a vortex and then filtered through a $180 \mu \mathrm{m}$ mesh filter. Fifteen $\mathrm{mL}$ of glutaraldehyde (2\% final concentration) were added to the sample. Afterwards, the sample was shaken and filtered again. The process was repeated six times, and all filtrate fractions were combined to obtain a final composite sample of $110 \mathrm{~mL}$. 
Biomass



Abundance

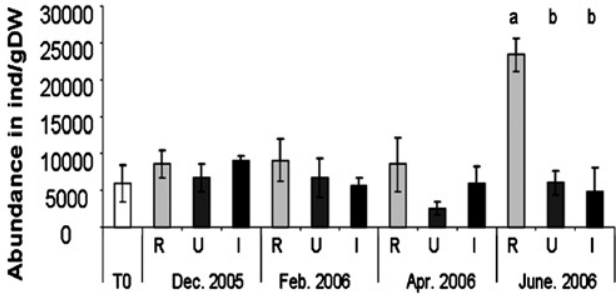

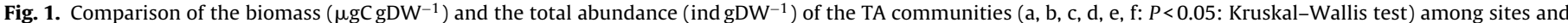
sampling time (mean $\pm \mathrm{sd}$ ).

\subsubsection{Analysis}

Ten $\mathrm{mL}$ or $15 \mathrm{~mL}$ of the final composite sample were analysed at $400 \times$ with an inverted microscope in accordance with the Uthermöhl method (Uthermöhl, 1958). The active and encysted tests were counted separately. Between 115 and 384 tests were counted for each sample.

\subsubsection{Estimation of biovolume and biomass}

The biovolume of each species was considered equivalent to geometrical shapes and then converted to carbon using the following conversion factor: testate amoebae, $1 \mu \mathrm{m}^{3}=1.1 \times 10^{-7} \mu \mathrm{gC}$ (Weisse et al., 1990). These data were expressed as $\mu \mathrm{gC}$ per gram of $P$. purum dry weight $\left(\mu g C \mathrm{gDW}^{-1}\right)$.

\subsection{Numerical analysis}

To analyse the two components of TA community diversity, Hill's numbers and Hill's ratios (Hill, 1973; Alatalo, 1981) were used. The first component, species richness, $N_{0}$, is simply the total number of observed species. The second component, species evenness, $E_{2,0}=N_{2} / N_{0}$, was computed as the Hill's ratio between inverse Simpson's diversity, $N_{2}$, and species richness, $N_{0}$, (Gillet et al., 1999). This ratio represents the proportion of dominant species in the community, irrespective of species richness. As in all our statistical analyses, we used biomass instead of abundance compute, $N_{2}$. Biomass allows for more weight to be given to species with a big size but a low density. From an ecological point of view, relative biomass is therefore a better representation of the respective contribution of each species in the community than relative abundance.Due to the low number of samples (three per site and per sampling occasion), nonparametric statistical tests were performed. The biomass, abundance, taxa richness and evenness of TA community were compared using Kruskal-Wallis tests. Kruskal-Wallis tests were also used to compare the three sites by their $\mathrm{NO}_{2}$ and MTE concentrations.

The dynamics of the testate amoeba community in response to environmental conditions was analysed by Redundancy Analysis (RDA) and by Principal Response Curves (PRC). RDA (Ter Braak and Smilauer, 1998) was performed after forward selection of the environmental variables, using the method described in Blanchet et al. (2008) and implemented in the packfor R package (Dray et al., 2007). All biomass data were $\ln (x+1)$ transformed to stabilise variance and reduce the influence of dominant taxa on the ordination.

A PRC analysis was performed using the prc function of the vegan $R$ package (Oksanen et al., 2010). PRC was used to determine the multivariate response of the TA community at the polluted urban and industrial sites over time, as compared to the rural site (Van den Brink and Ter Braak, 1999; Moser et al., 2007). This method makes it possible to summarise effects on all the species of the community and to display them in a single diagram. PRC extracts information from this part of the variance only, which is explained by the treatment (here: site) and time, implemented as covariables.
The PRC standardises the control (here: rural site) to be zero-valued for all times, that is, a horizontal line in the PRC diagram. The PRC scores for each of the treatments through time represent compositional deviations from the control.

\section{Results}

\subsection{Characterisation of study sites}

Meteorological and atmospheric $\mathrm{NO}_{2}$ concentrations data were presented in detail by Meyer et al. (2010a).

\subsubsection{Meteorological data}

The rural site was characterised by lower temperatures than the other two sites, including reaching negative temperatures in the winter.

\subsubsection{Atmospheric $\mathrm{NO}_{2}$ concentrations}

During the whole period of exposure, $\mathrm{NO}_{2}$ concentration was significantly higher at the urban and industrial sites than at the rural site $(P<0.001)$, and from February to June, $\mathrm{NO}_{2}$ concentration was significantly higher at the urban site than at the industrial site $(P<0.001)$.

\subsubsection{Trace element concentrations in P. purum}

The analysis by INAA and ICP-MS showed a difference of MTE concentrations in P. purum. At the beginning of the study, no differences were observed among the three sites. The data of MTE concentrations in bryophytes are shown in Table 1. After four months of exposure, Fe concentrations were significantly higher at the industrial site than at the urban or rural site, and were significantly higher at the urban site than at the rural site. After six months of exposure, the concentrations of $\mathrm{Fe}, \mathrm{Pb}$ and $\mathrm{Cr}$ were significantly higher at the industrial site than at the urban or rural site, and were significantly higher at the urban site than at the rural site. Finally, after eight months of exposure, the concentrations of $\mathrm{Fe}, \mathrm{Al}$ and $\mathrm{Cr}$ were significantly higher at the industrial site than at the urban or rural site and were significantly higher at the urban site than at the rural site.

\subsection{Dynamics of ecological indexes of testate amoeba community}

Statistically significant seasonal effects were found for the total biomass and abundance at the rural site (higher in June).

\subsubsection{Biomass}

At the beginning of the study (samples T0), the biomass of $\mathrm{TA}$ was $64 \mu \mathrm{gC} \mathrm{gDW}^{-1}$. During this study, the biomass evolved differently depending on the site. After four and eight months of exposure, that is, in February and June, biomass was significantly higher at the rural site than at the urban or industrial site ( $P=0.03$ and $P=0.0002$, respectively) (Fig. 1 ). In detail, the biomass 


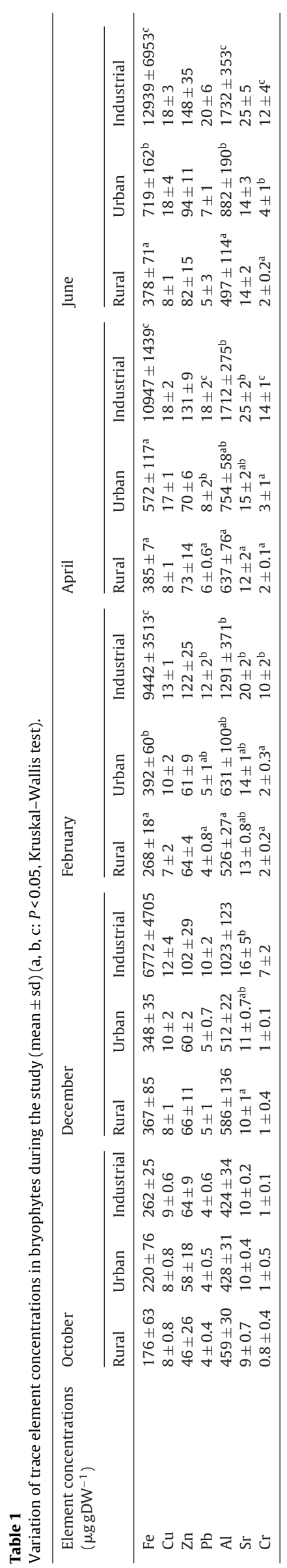

of Trigonopyxis arcula was significantly higher at the rural site than at the polluted sites in February. In June, the biomasses of seven species were significantly higher at the rural site than at the polluted sites (Cyclopyxis sp., E. ciliata vs glabra, Lesquereusia modesta, Nebela flabellulum, Nebela tincta, Trinema sp. and T. arcula).

\subsubsection{Abundance}

At the beginning of the study (samples T0), the total abundance of the TA species was 5945 ind $\mathrm{gDW}^{-1}$, and the community was heavily dominated by one species: $N$. tincta (22\% of the TA community) (Table 2). After eight months of exposure, in June, the total abundance of the TA community was significantly higher at the rural site than at the urban or industrial site $(P=0.0001)$ (Fig. 1). Specifically, the rural community was heavily dominated by three species representing $45 \%$ of the TA community: L. modesta, $N$. tincta and Assulina muscorum; the urban community was heavily dominated by two species representing 55\% of the TA community: Archerella flavum and $L$. modesta, and the industrial community was heavily dominated by two species representing $53 \%$ of the TA community: L. modesta and $N$. tincta. In contrast, it would seem that Hyalosphenia elegans and Bullinularia indica were rarely present at the rural and urban sites, whereas Difflugia sp. was rarely present at the industrial site (Table 2).

Moreover, after six months of exposure B. indica and Centropyxis sp. had disappeared from the industrial site. After eight months, $A$. muscorum and $H$. elegans had also disappeared from the industrial site, and Difflugia sp. and Nebela militaris had disappeared from the urban site.

\subsubsection{Species richness and evenness}

At the beginning of the study, species richness was $18 \pm 3$. At each time of sampling, taxa richness was significantly higher at the rural site than at the urban or industrial site $(P=0.01, P=0.002$, $P=0.003$ and $P=0.007$, respectively). However, at each time of sampling, there was no difference in evenness among sites (Fig. 2).

More specifically, at the urban site, species richness was significantly higher in October and December than in April and June $(P=0.02)$, while evenness was significantly higher in February and June than in October $(P=0.02)$ (Fig. 2). Furthermore, species richness was negatively correlated with time $\left(r^{2}=0.74 ; P<0.0001\right)$, while evenness was positively correlated with time. $\left(r^{2}=0.43\right.$; $P=0.008$ ). At the industrial site, species richness was significantly higher in October than in February and June $(P=0.02)$ and was negatively correlated with time $\left(r^{2}=0.57 ; P=0.001\right)$.

\subsection{Relationships between physico-chemical environmental variables, trace elements accumulated in P. purum and microbial communities}

Redundancy Analysis shows that the best model included $\left[\mathrm{NO}_{2}\right]$, [Cu], relative humidity $(\mathrm{RH})$, temperature and time as explanatory variables. Put together, they explained $40.5 \%$ of the variance in the TA community data $\left(r^{2}=0.405, P=0.001\right)$. Fig. 3 illustrates the correlations between environmental variables and the TA community over the first two canonical axes. Significant axes 1 and 2 explain respectively $22.16 \%$ and $9.69 \%$ of the variation of the TA community ( $P=0.001$ for axis 1 and $P=0.009$ for axis 2, Monte-Carlo permutation test, 1000 permutations). Fig. 3 also clearly indicates that axis 1 is explained mainly by $\left[\mathrm{NO}_{2}\right]$ and that axis 2 is mainly explained by time and relative humidity. RDA shows that $N$. tincta, T. arcula and Arcella vulgaris were strongly negatively correlated with $\mathrm{NO}_{2}$; Cyclopyxis sp. and Nebela collaris were strongly positively correlated with relative humidity; Nebela carinata was positively correlated with time and Euglypha strigosa was negatively correlated with $\mathrm{Cu}$.

Because RDA showed the significant impact of time, Principal Response Curve analysis allowed for the display of the dynamics 
Table 2

Testate amoebae abundance (ind $\mathrm{gDW}^{-1}$ ) at the beginning and the end of exposition (mean $\pm \mathrm{sd}$ ).

\begin{tabular}{|c|c|c|c|c|}
\hline \multirow[t]{2}{*}{ Species } & \multirow[t]{2}{*}{ October } & \multicolumn{3}{|l|}{ June } \\
\hline & & Rural & Urban & Industrial \\
\hline Archerella flavum & $54 \pm 93$ & & $1416 \pm 2255$ & \\
\hline Arcella vulgaris & $421 \pm 268$ & $401 \pm 179$ & $77 \pm 133$ & $131 \pm 227$ \\
\hline Assulina muscorum & $263 \pm 294$ & $2237 \pm 1551$ & $327 \pm 225$ & \\
\hline Assulina seminulum & $165 \pm 167$ & $951 \pm 369$ & $498 \pm 131$ & $335 \pm 217$ \\
\hline Bullinularia indica & $374 \pm 230$ & $71 \pm 123$ & $30 \pm 53$ & \\
\hline Centropyxis sp. & $45 \pm 77$ & & & \\
\hline Corythion dubium & $472 \pm 202$ & $944 \pm 1034$ & $122 \pm 211$ & $440 \pm 592$ \\
\hline Cyclopyxis sp. & $56 \pm 96$ & $1566 \pm 881$ & & \\
\hline Difflugia sp. & $186 \pm 99$ & $742 \pm 245$ & & $22 \pm 38$ \\
\hline Euglypha ciliata vs glabra & $18 \pm 31$ & $1014 \pm 413$ & $209 \pm 290$ & \\
\hline Euglypha compressa & $296 \pm 253$ & $435 \pm 387$ & $339 \pm 510$ & $226 \pm 210$ \\
\hline Euglypha strigosa & $357 \pm 533$ & $1769 \pm 1699$ & $106 \pm 117$ & $119 \pm 206$ \\
\hline Heleopera sp. & $22 \pm 29$ & & & $284 \pm 491$ \\
\hline Hyalosphenia elegans & $60 \pm 103$ & $60 \pm 104$ & $26 \pm 44$ & \\
\hline Lesquereusia modesta & $276 \pm 127$ & $3875 \pm 3367$ & $1385 \pm 384$ & $1181 \pm 692$ \\
\hline Nebela carinata & $159 \pm 158$ & $842 \pm 365$ & $383 \pm 254$ & $359 \pm 360$ \\
\hline Nebela collaris & $239 \pm 252$ & $38 \pm 66$ & & \\
\hline Nebela flabellulum & $256 \pm 386$ & $412 \pm 386$ & & \\
\hline Nebela militaris & $26 \pm 46$ & $40 \pm 69$ & & $59 \pm 103$ \\
\hline Nebela tincta & $1313 \pm 452$ & $4069 \pm 1547$ & $672 \pm 337$ & $966 \pm 677$ \\
\hline Trinema sp. & $369 \pm 86$ & $2704 \pm 2206$ & $167 \pm 74$ & $59 \pm 103$ \\
\hline Trigonopyxis arcula & $281 \pm 178$ & $774 \pm 445$ & & \\
\hline
\end{tabular}

of the TA community. This analysis considers variations of controls as baseline. In this study, the rural site is the control. Each species is attributed a score according to its contribution to deviations of the community due to the different site conditions. A positive score within the diagram indicates a reduced biomass of the species in the polluted sites compared to the control. The PRC diagram of the
TA community living in bryophytes shows a deviation from the control for the urban and industrial sites (Fig. 4). The stars show a significant difference between the total TA biomass at the polluted sites and at the rural site (control).

PRC revealed that $33.4 \%$ of the total variance of the TA community data is explained by time and $29.1 \%$ by site. The first canonical
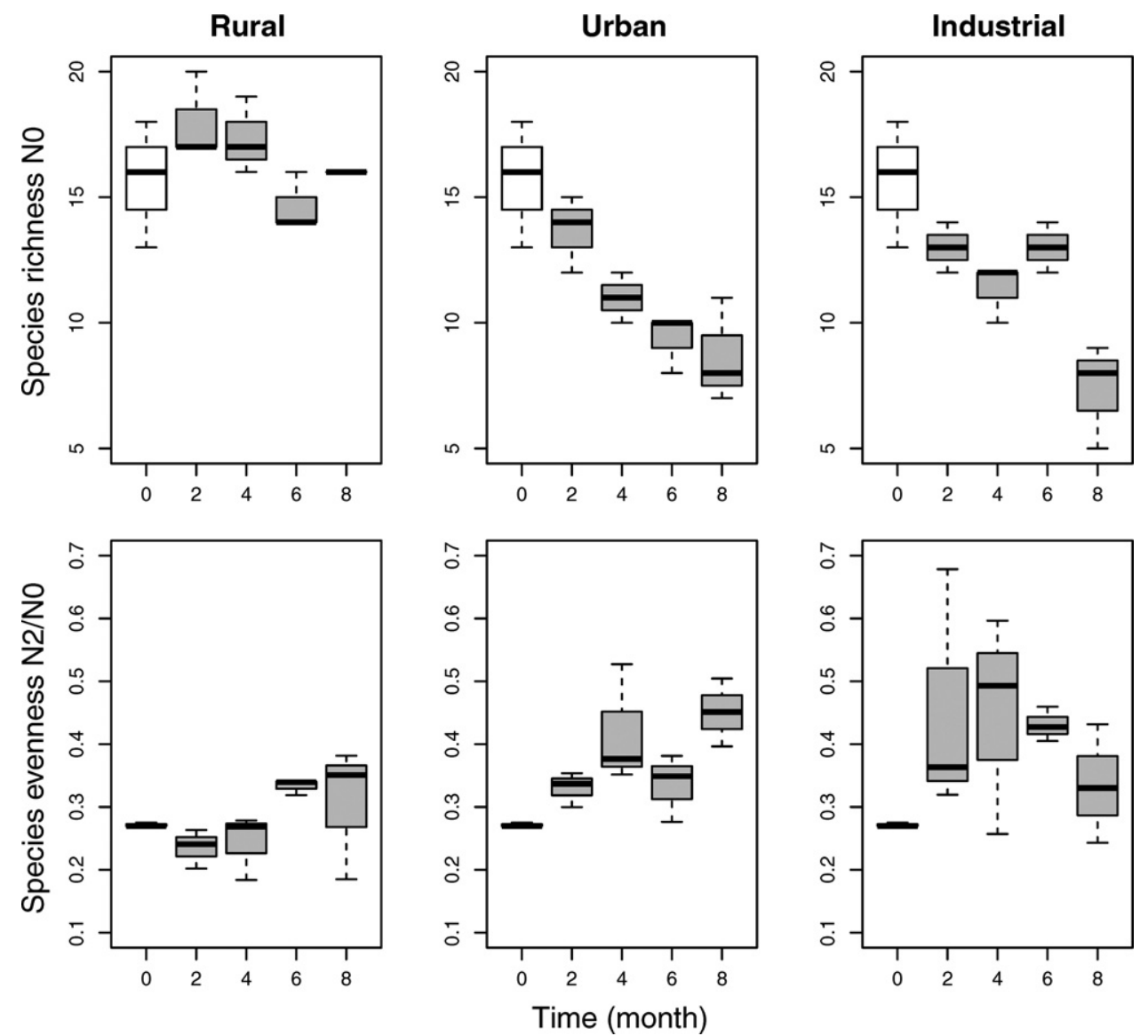

Fig. 2. Comparison of testate amoeba species richness and evenness among sites and over time. 


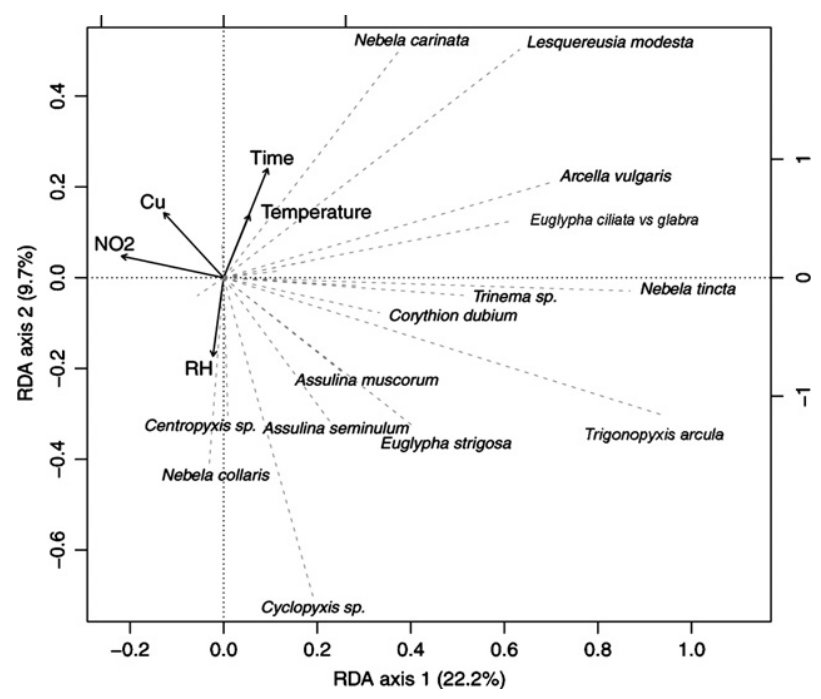

Fig. 3. Redundancy analysis (axes 1 and 2) of the TA community data, after forward selection of the explanatory variables (physico-chemical environmental variables including trace element concentrations in bryophytes). Only species far from the origin are labelled.

axis of the PRC captured the only statistically significant part of the variance explained by the treatment $(P=0.0014$, Monte Carlo permutation test, 10,000 permutations). The highest responses were obtained for T. arcula (1.10), N. tincta (0.70) and A. vulgaris (0.68).

\section{Discussion}

4.1. Study sites, metal trace elements accumulation and TA diversity in the microsystem

The characterisation of study sites and MTEs accumulation were discussed in our previous study (Meyer et al., 2010a). Briefly, the three sites were characterised by different climatic conditions and different atmospheric pollution. The urban site showed significant contamination with $\mathrm{NO}_{2}$, in agreement with its localisation near a highway, while the most serious pollution by MTEs was found at the industrial site, in agreement with the presence of metallurgical plants in the area (Gaudry et al., 2008).

$P$. purum is used to biomonitor atmospheric pollution (Zechmeister et al., 2005; Amblard-Gross et al., 2002; Fernández and Carballeira, 2001). In France, this bryophyte species is used by

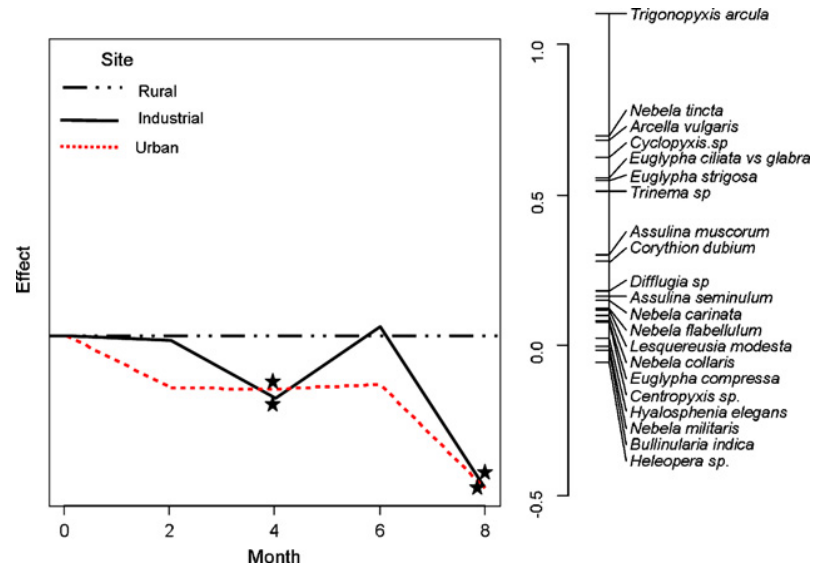

Fig. 4. Principal response curves with species weights for the TA community data, indicating the effect of sites. The $\operatorname{star}(\star)$ shows a significant difference of TA biomass between the control (rural site) and the polluted sites $(P<0.05$, Kruskal-Wallis test). the program BRAMM/PIC to monitor MTE atmospheric fallout in a rural zone (Galsomies et al., 1999). Furthermore, the morphology of P. purum is adapted to the development of microorganisms: broader leaves and more numerous ramifications (Augier, 1966; Shaw and Goffinet, 2000) can keep humidity higher for greater development of a TA community ( $18 \pm 3$ species at the rural site). TA species richness is dependent on moss species identity, geographical location, sampling strategy (length of stem removed, number of samples and number of sampled mosses) and moss moisture (Bonnet, 1973). In the terrestrial mosses, Nguyen-Viet et al. (2004, 2007a) found nine species in T. muralis (Besançon, France) and 23 species in B. indica (Hanoi, Vietnam), while Mieczan (2009) identified 45 TA taxa in the semi-aquatic mosses (Sphagnum). For these reasons, it is difficult to compare diversity of the TA community among different ecotoxicological studies. What is more, in this new field there is no standardised method for bioindication using a TA community?

\subsection{Effects of atmospheric pollution on testate amoebae community and using ecological indexes as indicators}

Different parameters can be used as indicators of atmospheric pollutants: appearance/extinction of species or decrease in specific biomass/abundance. This study showed a specific impact of atmospheric $\mathrm{NO}_{2}$ and those particulate pollutions on the TA species living in $P$. purum. N. tincta, T. arcula and $A$. vulgaris are sensitive to $\mathrm{NO}_{2}$ while E. strigosa is sensitive to $\mathrm{Cu}$ (Fig. 3). Moreover, A. vulgaris was rarely present and Difflugia sp. disappeared at the urban site, while B. indica and Centropyxis sp. disappeared after six months of exposure and $A$. muscorum after eight months at the industrial site. At the urban site, the species responses are in accordance with the results found in other environments. In waste water and sediments, Arcella sp. and Difflugia sp. are known to be sensitive to $\mathrm{Cu}$ pollution (Nicolau et al., 2005; Kauppila et al., 2006). However, the species responses at the industrial site are in contradiction to the results of Patterson et al. (1996) in water and Asada and Warner (2009) in soil. In these studies, Centropyxis sp. was abundant in environments polluted by $\mathrm{As}, \mathrm{Hg}$ and $\mathrm{Cu}$.

The species-specific response of the TA community can be used as a bioindicator of atmospheric pollutants and, in the " $P$. purumTA" microsystem, can be used to differentiate the pollution sources (urban or industrial). The diversity and species composition of TA communities varies according to the biotope, so it is difficult to compare different species-specific responses of the TA community in different studies. That is why it is necessary to use global descriptors that are not based on the species composition as indicators of atmospheric pollution and its integration into ecosystems (integrative stress indicators) (Fränzle, 2006).

Our study also showed that atmospheric pollutions have a negative impact on TA community biomass, abundance and species richness (Figs. 1 and 2). Whatever the biotope (other mosses, soil, and sediments), the global responses of the TA community exposed to medium/high-level pollution, such as decrease of total biomass, abundance and species richness, are the same as those observed in our study (Nguyen-Viet et al., 2004, 2007a; Kauppila et al., 2006). The low-level pollution also has similar negative impacts on TA communities, such as a decrease in biomass or abundance of active TA or in the biomasses of different species (Meyer et al., 2010b; Payne et al., 2010). Other global ecological indexes could be used as indicators of atmospheric pollution. TA species found in this study are predators or mixotrophic (predator with algae symbiosis) in the microbial food web, and each species has a different diet (Gilbert et al., 2000). In soil, trophic groups of nematodes have been used for bioindication of pollution (Pen-Mouratov et al., 2008; Heininger et al., 2007). In the same way, trophic groups of TA living in bryophytes could be used in the bioindication of atmospheric pollution. It would seem that the generalist species like $N$. tincta are 
more sensitive to pollution, probably because of direct and indirect effect of pollutants. In our previous study (Meyer et al., 2010a), we showed that atmospheric pollution had an impact on the different groups of microbial communities. However, the diet of the species encountered in this study has not been studied sufficiently in the scientific literature. When this type of data is available, an index could be suggested, taking into account the direct and indirect effects of atmospheric pollutants and their integration into ecosystems.

Furthermore, this study showed that climatic conditions, especially temperature and relative humidity, have an impact on the TA community (Fig. 3). These results are in accordance with the results of other studies in other environments (Mitchell et al., 1999; Warner et al., 2007; Beyens et al., 2009), where the diversity and abundance of TA are dependent on environmental conditions such as humidity, $\mathrm{pH}$, soil moisture or temperature.

Nevertheless, temperature and relative humidity were dependent on time. Therefore, it is necessary to consider the dynamics of the community to choose a good indicator of pollution. Time series of total biomass, total abundance and species richness can be used as integrative stress indicators of atmospheric pollution. Moreover, PRC and RDA appear to be good tools to summarise the response of a TA community over time when it is affected by different atmospheric pollutions and could be used as a tool for statistical bioindication. Furthermore, PRC analysis showed that urban pollution did not have the same effect as industrial pollution on TA community biomass (Fig. 4).

\section{Conclusion}

It is important to have valid indicators for the possible effects of pollution, especially for areas that are polluted with a cocktail of different atmospheric compounds, including particles and gases. The "bryophyte-TA" microsystem combines the advantages of active bioindication methods using bryophytes only with the use of sensitive microorganisms that give earlier responses (Meyer et al., 2010b). Moreover, this microsystem permits the development of a compact system whose size is small and which is easy to manipulate. This microsystem can also be used in an environment where the native bryophytes cannot grow. Furthermore, this study showed that simple parameters such as total biomass or total abundance of TA living in "bryophyte-testate amoebae" microsystems are good indicators of atmospheric pollution. More specifically, species-specific responses of a TA community living in "P. purumTA" microsystems are not only good indicators of atmospheric pollution but also of the sources of pollution (urban or industrial). Nevertheless, other studies are needed to develop a standardised tool for the biomonitoring of air quality using "bryophyte-TA" microsystems. Further studies are needed to improve knowledge of TA ecology and to try to find a trophic diversity index as an indicator of atmospheric pollution.

\section{Acknowledgements}

The present work was financially supported by the PrimequalPredit program and the city of Besançon. Authors thank Meteo France for their collaboration in weather data acquisition. They also thank Julie Jeunot and Donna L'Hôte for their help in the English revision. Finally, they thank the two anonymous reviewers for their constructive comments.

\section{References}

Aboal, J.R., Couto, J.A., Fernández, J.A., Carballeira, A., 2008. Physiological responses to atmospheric fluorine pollution in transplants of Pseudoscleropodium purum. Environ. Pollut. 153 (3), 602-609.
Alatalo, R.V., 1981. Problems in the measurement of evenness in ecology. Oikos 37, 199-204.

Alves, C., Pio, C., Duarte, A., 2001. Composition of extractable organic matter of air particles from rural and urban Portuguese areas. Atmos. Environ. 35, 5485-5496.

Amblard-Gross, G., Férard, J.F., Carrot, F., Boonin-Mosbah, M., Maul, S., Ducruet, J.M. Coddeville, P., Béguinel, P., Ayrault, S., 2002. Biological fluxes conversion and SXRF experiment with a new active biomonitoring tool for atmospheric metals and trace element deposition. Environ. Pollut. 120 (1), 47-58.

Asada, T., Warner, B.G., 2009. Plants and testate amoebae as environmental bioindicators in cupriferous peatlands, New Brunswick, Canada. Ecol. Indicat. 9, $129-137$.

Augier, J., 1966. Flore des bryophytes. Lechevallier, Paris, p. 702.

Beyens, L., Ledeganck, P., Graae, B.J., Nijs, I., 2009. Are soil biota buffered against climatic extremes? An experimental test on testate amoebae in artic tundra (Qeqertarsuacq, West Greenland). Polar Biol. 32, 453-462.

Blake, D., Hinwood, A.L., Horwitz, P., 2009. Peat fires and air quality: volatile organic compounds and particulates. Chemosphere 76, 419-423.

Blanchet, F.G., Legendre, P., Borcard, D., 2008. Forward selection of explanatory variables. Ecology 89, 2623-2632.

Bonnet, L., 1973. Le peuplement thécamoebiens des mousses corticoles. Protistologica 9 (3), 319-338.

Byrd, T., Stack, M., Furey, A., 2010. The assessment of the presence and main constituents of particulate matter ten microns $\left(\mathrm{PM}_{10}\right)$ in Irish, rural and urban air. Atmos. Environ. 44 (1), 75-87.

Coordination technique de la surveillance de la qualité de l'air (ADEME, LCSQA Fédération Atmo), 2002. Echantillonneurs passifs pour le dioxyde d'azote. ADEME, édition Paris, 143 p.

Dray, S., Legendre, P., Blanchet, F.G., 2007. Packfor: forward selection with permutation. R Package Version 0.0-7. http://r-forge.r-project.org/R/?group_id=195.

Fabure, J., Meyer, C., Denayer, F., Gaudry, A., Gilbert, D., Bernard, N., 2010. Accumulation capacities of particulate matter in an acrocarpous and a pleurocarpous moss exposed at three differently polluted sites (industrial, urban and rural) Water Air Soil Pollut. 212 (1-4), 205-217.

Fernández, J.A., Carballeira, A., 2001. A comparison of indigenous mosses and topsoils for use in monitoring atmospheric heavy metal deposition in Galicia (northwest Spain). Environ. Pollut. 114, 431-441.

Fränzle, O., 2006. Complex bioindication and environmental stress assessment. Ecol. Indicat. 6, 114-136.

Gallego, A., Martin-Gonzáles, A., Ortega, R., Gutiérrez, J.C., 2007. Flow cytometry assessment of cytotoxicity and reactive oxygen species generation by single and binary mixture of cadmium, zinc and copper on populations of the ciliated protozoan Tetrahymena thermophila. Chemosphere 68, 647-661.

Galsomies, L., Letrouit, M.A., Deschamps, C., Savanne, D., Avnaim, M., 1999. Atmospheric metal deposition in France: initial results on moss calibration from the 1996 biomonitoring. Sci. Total Environ. 232, 39-47.

Gaudry, A., Moskura, M., Mariet, C., Ayrault, S., Denayer, F., Bernard, N., 2008. Inorganic pollution in $\mathrm{PM}_{10}$ particles collected over three French sites under various influences: rural conditions, traffic and industry. Water Air Soil Pollut. 193, 91-106.

Gilbert, D., Francez, A.J., Amblard, G., Bourdier, G., 1999. The microbial communities at the surface of the Sphagnum peatlands: good indicators of human disturbances? Ecologie 30, 45-52.

Gilbert, D., Amblard, C., Bourdier, G., Francez, A.J., Mitchell, E.A.D., 2000. Le régime alimentaire des Thécamoebiens (Protista, Sarcodina). Ann. Biol. 39, 57-68.

Gillet, F., Murisier, B., Buttler, A., Gallandat, J.-D., Gobat, J.-M., 1999. Influence of tree cover on the diversity of herbaceous communities in subalpine wooded pastures. Appl. Veg. Sci. 2, 47-54.

Golemansky, V.G., Todorov, M.T., 2000. Testate amoebae (Protozoa: Rhizopoda) from Thailand. Acta Protozool. 39, 337-344

Han, B., Bai, Z., Ji, H.L., Guo, G., Wang, F., Shi, G., Li, X., 2009. Chemical characterization of $\mathrm{PM}_{10}$ fraction of paved road dust in Anshan, China. Transport. Res. Part D 14 (8), 599-603.

Heininger, P., Höss, S., Claus, E., Pelzer, J., Traunspurger, W., 2007. Nematode communities in contaminated river sediments. Environ. Pollut. 146, 64-76.

Hill, M.O., 1973. Diversity and evenness: a unifying notation and its consequences. Ecology 54, 427-432.

Kauppila, T., Kihlman, S., Mäkinen, J., 2006. Distribution of arcellaceans (testate amoebae) in the sediments of a mine water impacted bay of lake Retunen Finland. Water Air Soil Pollut. 172, 337-358.

Khan, S., Cao, Q., Hesham, A.E.L., Xia, Y., He, J., 2007. Soil enzymatic activities and microbial community structure with different application rates of $\mathrm{Cd}$ and $\mathrm{Pb}$. J. Environ. Sci. 19, 834-840.

Markert, B., 2007. Definitions and principles for bioindication and biomonitoring of trace metals in the environment. J. Trace Elem. Med. Biol. 21, 77-82.

Martin-Gonzáles, A., Diaz, S., Borniquel, S., Gallego, A., Gutiérrez, J.C., 2006. Cytotoxicity and bioaccumulation of heavy metals by ciliated protozoa isolated from urban wastewater treatment plants. Res. Microbiol. 157, 108-118.

Meisterfeld, R., 2000a. Order arcellinida kent, 1880. In: Lee, J.J., Leedale, G.F., Bradbury, P. (Eds.), The Illustrated Guide to the Protozoa, Society of Protozoologists. Lawrence, Kansas, pp. 827-860.

Meisterfeld, R., 2000b. Testate amoebae with filopodia. In: Lee, J.J., Leedale, G.F., Bradbury, P. (Eds.), The Illustrated Guide to the Protozoa, Society of Protozoologists. Lawrence, Kansas, pp. 1054-1084.

Meyer, C., Gilbert, D., Gaudry, A., Franchi, M., Nguyen-Viet, H., Fabure, J., Bernard, N., 2010a. Relationship of atmospheric pollution characterized by gas $\left(\mathrm{NO}_{2}\right)$ and 
particles $\left(\mathrm{PM}_{10}\right)$ to microbial communities living in bryophytes at three differently polluted sites (Rural, Urban and Industrial). Microb. Ecol. 59 (2), 324-334.

Meyer, C., Bernard, N., Moskura, M., Toussaint, M.L., Denayer, F., Gilbert, D., $2010 \mathrm{~b}$. Effect of urban particulate deposition on microbial communities living in bryophytes: an experimental study. Ecotox. Environ. Safe. 73, 1776-1784.

Mieczan, T., 2009. Ecology of testate amoebae (Protists) in Sphagnum peatlands of eastern Poland: vertical micro-distribution and species assemblages in relation to environmental parameters. Ann. Limnol. Int. J. Lim. 45, 41-49.

Mitchell, E.A.D., Buttler, A.J., Warner, B.G., Gobat, J.M., 1999. Ecology of testate amoebae (Protozoa: Rhizopoda) in Sphagnum peatlands in the Jura mountains, Switzerland and France. Ecoscience 6 (4), 565-576.

Mitchell, E.A.D., Charman, D.J., Warner, B.G., 2008. Testate amoebae analysis in ecological and paleoecological studies of wetlands: past, present and future. Biodivers. Conserv. 17, 2115-2137.

Moser, T., Römbke, J., Schallnass, R.J., Van Gestel, C.A.M., 2007. The use of the multivariate Principal Response Curve (PRC) for community level analysis: a case study on the effects of carbendazim on enchytraeids on Terrestrial Model Ecosystems (MTE). Ecotoxicology 16, 573-583.

Nguyen-Viet, H., Gilbert, D., Bernard, N., Mitchell, E.A.D., Badot, P.M., 2004. Relationship between atmospheric pollution characterised by $\mathrm{NO}_{2}$ concentrations and testate amoebae abundance and diversity. Acta Protozool. 43, 233-329.

Nguyen-Viet, H., Bernard, N., Mitchell, E.A.D., Cortet, J., Badot, P.M., Gilbert, D., 2007a. Relationship between testate amoeba (Protist) communities and atmospheric heavy metals accumulated in Barbula indica (Bryophyta) in Vietnam. Microb. Ecol. 53, 53-65.

Nguyen-Viet, H., Gilbert, D., Mitchell, E.A.D., Badot, P.M., Bernard, N., 2007b. Effects of experimental lead pollution on the microbial communities associate with Sphagnum fallax (Bryophyta). Microb. Ecol. 54 (2), 232-241.

Nguyen-Viet, H., Bernard, N., Mitchell, E.A.D., Badot, P.M., Gilbert, D., 2008. Effect of lead pollution on testate amoebae communities living in Sphagnum fallax: an experimental study. Ecotox. Environ. Safe. 69, 130-138.

Nicolau, A., martins, M.J., Mota, M., Lima, N., 2005. Effect of copper in the protistan community of activated sludge. Chemosphere 58 (5), 605-614.

Nwuche, C.O., Ugoji, E.O., 2008. Effects of heavy metal pollution on the soil microbial activity. Int. J. Environ. Sci. Technol. 5 (2), 409-414.

Oksanen, J., Blanchet, F.G., Kindt, R., Legendre, P., O'Hara, R.B., Simpson, G.L., Solymos P., Stevens, M.H.H., Wagner, H., 2010. Vegan: Community Ecology Package. R package version 1.17-3. http://CRAN.R-project.org/package=vegan.

Palmes, E.D., Gunnison, A.F., DiMattio, J., Tomczik, C., 1976. Personal sampler for nitrogen dioxide. Am. Ind. Hyg. Assoc. J. 37 (10), 570-577.
Patterson, R.T., Barker, T., Burbidge, S.M., 1996. Arcellaceans (thecamoebians) as proxies of arsenic and mercury contamination in northeastern Ontario Lakes. J. Foramin. Res. 6 (2), 172-183.

Payne, R., Gaucy, V., Charman, V.J., 2010. The impact of simulated sulfate deposition on peatland testate amoebae. Microb. Ecol. 59, 76-83.

Pen-Mouratov, S., Shukurov, N., Steinberger, Y., 2008. Influence of industrial heavy metal pollution on soil free-living nematode population. Environ. Pollut. 152, 172-183.

Roe, H.M., Patterson, T., Swindles, G.T., 2010. Controls on the contemporary distribution of lake Thecamoebians (testate amoebae) within the Greater Toronto Area and their potential as water quality indicators. J. Palealimnol. 43 (4), 955-975.

Shaw, J., Goffinet, B., 2000. Bryophyte Biology. Cambridge University Press, pp: 486.

Slezakova, K., Pires, J.C.M., Pereira, M.C., Martins, F.G., Alvin-Ferraz, M.C., 2008. Influence of traffic emission on the composition of atmospheric particles of different sizes-Part 2: SEM-EDS characterization. J. Atmos. Chem. 60, 221-236.

Smith, H.G., Bobrov, A., Lara, E., 2008. Diversity and biogeography of testate amoebae. Biodivers. Conserv. 17, 329-343.

Ter Braak, C., Smilauer, P., 1998. Canoco Reference Manual and User's Guide to Canoco for Windows, Software for Canoco Community Ordination (Version 4). Centre for Biometry Wageningen, the Netherlands, pp. 31-145.

Thorpe, A., Harrison, R.M., 2008. Sources and properties of non-exhaust particulate matter from road traffic: a review. Sci. Total Environ. 400, 270-282.

Uthermöhl, H., 1958. Zur vervollkommnung der quantative phytoplanktonmethodik. Mitt. Inst. Verhein Limnol. 9, 1-38.

Van den Brink, P.J., Ter Braak, C., 1999. Principal response curves: analysis of time-dependent multivariate responses of the biological community to stress. Environ. Toxicol. Chem. 18, 138-148.

Vincke, S., Gremmen, N., Beyens, L., Van de vijver, B., 2004. The moss dwelling testacean fauna of Île de la Possession. Polar. Biol. 27, 753-766.

Warner, B.G., Asada, T., Quinn, N.P., 2007. Seasonal influences on the ecology of testate amoebae (Protozoa) in a small Sphagnum peatland in Southern Ontaria, Canada. Microb. Ecol. 54, 91-100.

Weisse, T., Muller, H., Pinto-Coelho, R.M., Schweizer, A., Springmann, D., Baldringer G., 1990. Response of microbial loop to the phytoplankton spring bloom in a larger prealpine lake. Limnol. Oceanogr. 35, 781-794.

Zechmeister, H.G., Hohenwallner, D., Riss, A., Hanus-Illnar, A., 2005. Estimation of element deposition derived from road traffic sources by using mosses. Environ. Pollut. 138 (2), 238-249.

Zhou, K., Xu, M., Dai, J., Cao, H., 2006. The microfauna communities and operationa monitoring of an activated sludge plant in China. Eur. J. Protistol. 42, 291-295. 